\title{
Penggunaan Metode Pembelajaran Learning Starts With A Question Sebagai Upaya Meningkatkan Prestasi Belajar Pkn
}

\author{
I Made Wirata Wiyadnyana ${ }^{1}$ \\ 1SD Negeri 4 Sidan, \\ Gianyar, Indonesia \\ email: wiratawiyadnyana6@mail.com
}

\begin{abstract}
Abstrak
Tujuan melakukan penelitian tindakan kelas ini adalah untuk meningkatkan prestasi belajar siswa kelas VI pada semester II. Subjek penelitian ini adalah siswa Kelas VI SD Negeri 4 Sidan. Cara yang dilakukan adalah menambah gaya pembelajaran lama yang konvensional menjadi cara pembelajaran baru yang bersifat penemuan menggunakan Metode Pembelajaran Learning starts with a question. Penelitian dilakukan dalam dua siklus yang masing-masing siklusnya dilakukan dengan tahap perencanaan, pelaksanaan, observasi, dan refleksi. Untuk mengumpulkan data hasil penelitian digunakan tes prestasi belajar dan untuk menganalisis datanya digunakan analisis deskriptif. Dilihat dari hasil evaluasi yang telah dilakkukan terjadi peningkatan dari data awal dengan rata-rata 69.75, ketuntasan belajar $35 \%$. Pada siklus I rata-ratanya 74,75 meningkat menjadi 81,5 pada siklus II dengan ketuntasan belajar $100 \%$. Dengan demikian dapat disampaikan simpulan bahwa penerapan Metode Pembelajaran Learning starts with a question dapat meningkatkan prestasi belajar PKN siswa kelas VI SD Negeri 4 Sidan Semester II Tahun Pelajaran 2017/2018.
\end{abstract}

Kata Kunci: Prestasi Belajar PKn, Metode Pembelajaran Learning Starts with A Question.

\begin{abstract}
The purpose of conducting this classroom action research is to improve the learning achievement of class VI students in the second semester. The subjects of this study were students of class VI SD Negeri 4 Sidan. The way this is done is to add the old conventional learning style into a new discovery learning method using the Learning starts with a question Learning Method. The research was conducted in two cycles, each of which was carried out by planning, implementing, observing, and reflecting. To collect data from the research results used learning achievement tests and to analyze the data used descriptive analysis. Judging from the results of the evaluation that has been done, there is an increase from the initial data with an average of 69.75 , learning completeness $35 \%$. In the first cycle the average was 74.75 , increasing to 81.5 in the second cycle with $100 \%$ learning completeness. Thus it can be concluded that the application of the Learning starts with a question Learning Method can improve the PKN learning achievement of class VI SD Negeri 4 Sidan Semester II for the 2017/2018 academic year
\end{abstract}

Keywords: Civics Learning Achievement, Learning Methods Learning Starts with a Question.

\section{Pendahuluan}

Dalam dunia pembelajaran dikenal adanya beberapa hal penting seperti media, metode, model, strategi, pendekatan dan teknik. Hal-hal tersebut mempunyai tujuan akhir yakni guna mencapai peningkatan dalam proses belajar mengajar. Dengan guru mampu melakukan pemilihan dan penggunaan hal-hal tersebut akan dapat mencapai hasil-hasil yang maksimal dari kegiatan belajar mengajar.

Masalah yang sedang dihadapi saat ini di Kelas VI di SD Negeri 4 Sidan betul-betul merupakan masalah pembelajaran dimana siswa di kelas ini belum aktif belajar. Maka masih menunggu perintah guru, masih kebiasaan dengan proses pengajaran yang konvensional

\footnotetext{
*Corresponding author.

Received 03 Februari 2020; Accepted 31 July 2020; Available online 1 September 2020

(c) 2020 MPI. All Rights Reserved
} 
yang memang penyebabnya adalah di pihak guru yang mengajar seperti itu. Guru belum mampu membuat peserta didik agar mampu menemukan sendiri sesuai prinsip pembelajaran masa kini. Proses pembelajaran yang dilakukan guru berhari-hari sama saja seperti itu. Hal inilah yang menjadi masalah sehingga peningkatan mutu pendidikan belum dapat diupayakan lebih maksimal.

Guna mencapai hasil yang maksimal, maka guru dituntut agar lebih tepat dalam menulis dan menentukan media, metode, model, strategi, pendekatan dan teknik yang digunakan dalam melaksanakan proses belajar mengajar. Yang tidak kalah penting juga adalah dikuasai atau tidaknya materi pelajaran yang diajar, dengan kata lain sebagai guru ternyata ada tuntutan untuk berolah kreatifitas secara langsung di hadapan siswa.

Ketersediaan waktu di sekoah untuk memperbaiki proses belajar mengajar menyebabkan peneliti melakukan penelitian yang berjudul "Penggunaan Metode learning starts with a question Sebagai Upaya Meningkatkan Prestasi Belajar PKn Siswa Kelas VI SD Negeri 4 Sidan Semester II Tahun Pelajaran 2017/2018". Dalam upaya memecahkan permasalahan yang penting dan mendesak di kelas ini. Selain ketersediaan waktu juga memilliki dana untuk menyelesaikan karya ini akibat dengan adanya dukungan yang memadai yang tersedia di sekolah ini.

Pelaksanaan proses pembelajaran menggunakan model tradisional atau konvensional belum membuahkan hasil sesuai harapan. Oleh karenanya penulis mulai memikirkan cara untuk memecahkan masalah yang mendesak untuk ditangani. Prestasi belajar siswa Kelas VI di SD Negeri 4 Sidan pada semester II masih jauh di bawah KKM pada mata pelajaran PKn di sekolah ini yaitu 75. Rata-rata yang diperoleh baru 69,75 dan ketuntasan belajar mereka baru mencapai $35 \%$. Perolehan hasil yang rendah tersebut merupakan masalah yang sesegera mungkin harus ditangani, itulah yang mendorong peneliti sehingga penelitian ini menjadi penting untuk dilaksanakan

\section{Metode Penelitian}

Penelitian yang dilaksanakan di SD Negeri 4 Sidan termasuk penelitian tindakan kelas. Dalam Penelitian Tindakan rancangan didesain dalam bentuk siklus dengan pemberian tindakan. Penelitian ini akan dilaksanakan dalam dua siklus yang setiap siklusnya terdiri dari tiga kali pertemuan untuk memberikan tindakan.

Dalam melaksanakan penelitian, rancangan merupakan hal yang sangat penting untuk disampaikan. Untuk maksud tersebut, penelitimenggunakan rancangan siklus penelitian tindakan yang disampaikan oleh Suharsimi (2007) terlihat pada gambar di bawah ini.

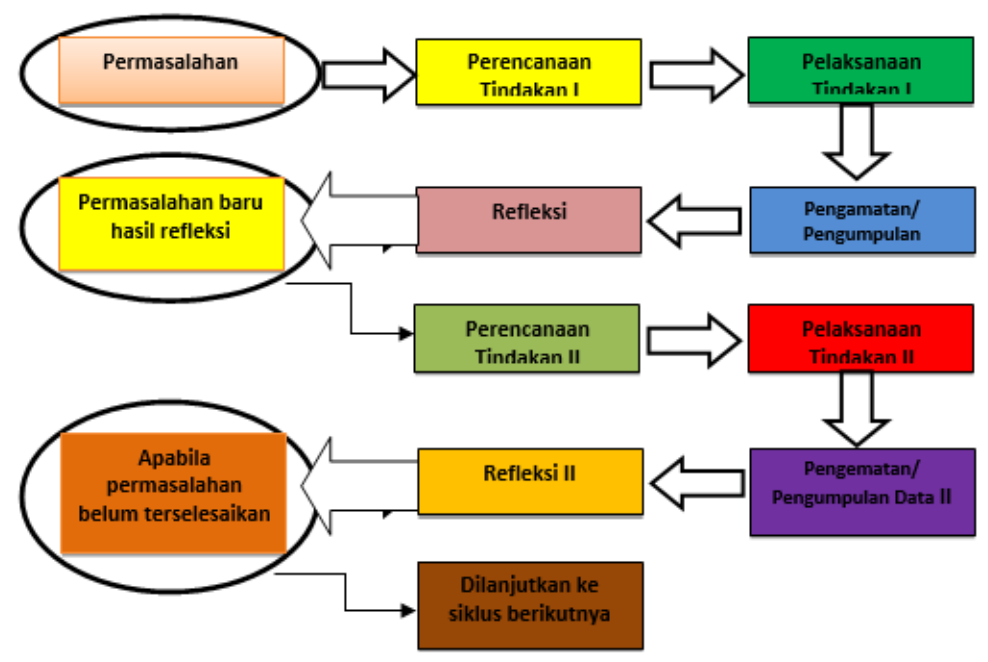

Gambar: 01 Alur Penelitian Tindakan Kelas (dalam Suharsimi Arikunto, Suhardjono, Supardi, 2006: 74) 


\section{Perencanaan} instrumen.

Pada tahap ini peneliti membuat RPP, berkonsultasi dengan teman sejawat membuat

Pada tahap menyusun rancangan diupayakan ada kesepakatan antara guru dan sejawat. Rancangan dilakukan bersama antara peneliti yang akan melakukan tindakan dengan guru lain yang akan mengamati proses jalannya tindakan. Hal tersebut untuk mengurangi unsur subjektivitas pengamat serta mutu kecermatan pengamatan yang dilakukan.

\section{Pelaksanaan Tindakan}

Tahap pelaksanaan tindakan dilakukan dengan pembelajaran di kelas. Pada tahap ini guru peneliti giat melakukan tindakan menggunakan Metode learning starts with a question. Rancangan tindakan tersebut sebelumnya telah dilatih untuk dapat diterapkan di dalam kelas sesuai dengan skenarionya. Skenario dari tindakan diupayakan dilaksanakan dengan baik dan wajar.

\section{Pengamatan atau observasi}

Tahap ini sebenarnya berjalan bersamaan dengan saat pelaksanaan. Pengamatan dilakukan pada waktu tindakan sedang berjalan, jadi, keduanya berlangsung dalam waktu yang sama.

Pada tahap ini, guru yang bertindak sebagai peneliti melakukan pengamatan dan mencatat semua hal yang diperlukan dan terjadi selama pelaksanaan tindakan berlangsung. Pengumpulan data ini dilakukan dengan menggunakan tes prestasi belajar yang telah tersusun, termasuk juga pengmatan secara cermat pelaksanaan skenario tindakan dari waktu ke waktu serta dampaknya terhadap proses dan hasil belajar siswa.

\section{Refleksi}

Tahapan ini dimaksudkan untuk mengkaji secara menyeluruh tindakan yang telah dilakukan, berdasarkan data yang telah terkumpul, kemudian dilakukan evaluasi guna menyempurnakan tindakan berikutnya.

Refleksi dalam PTK mencakup analisis, sintesis, dan penilaian terhadap hasil pengamatan atas tindakan yang dilakukan. Jika terdapat masalah dari proses refleksi maka dilakukan proses pengkajian ulang melalui siklus berikutnya yang meliputi kegiatan: perencanaan ulang, tindakan ulang, dan pengamatan ulang shingga permasalahan dapat teratasi.

Pengumpulan data dalam penelitian ini menggunakan tes prestasi belajar. Tes prestasi belajar berupa tes soal isian maupaun esay. Untuk menganalisis data hasil penelitian ini digunakan metode deskriptif. Untuk data kuantitatif dianalisis dengan mencari mean, median, modus, membuat interval kelas dan melakukan penyajian dalam bentuk tabel dan grafik. Indikator keberhasilan penelitian yang diusulkan dalam penelitian ini pada siklus I dan II mencapai nilai rata-rata 75,00 dengan ketuntasan belajar 85\%. dengan KKM yang ditetapkan untuk mata pelarajan PKN pada SD 4 Sidan adalah 75.

\section{Hasil Dan Pembahasan}

Metode pembelajaran dengan strategi learning starts with a question (LSQ) adalah suatu metode atau strategi pembelajaran aktif dengan cara merangsang keinginan siswa untuk bertanya kemudian guru menjelaskan apa yang ditanyakan oleh siswa. Metode learning starts with a question berkaitan dengan kemampuan bertanya dan menjawab. Bertanya dapat dipandang sebagai refleksi dari keingintahuan individu, sedangkan menjawab pertanyaan mencerminkan kemampuan seseorang dalam berpikir. Agar siswa aktif dalam bertanya, maka siswa diminta untuk mempelajari materi yang akan diajarkan, yaitu dengan membaca terlebih dahulu. Membaca akan membuat peserta didik memiliki gambaran tentang materi yang akan dipelajari, sehingga apabila dalam membaca atau membahas materi tersebut terjadi 
kesalahan pemahaman akan terlihat dan dapat dibahas serta dibenarkan secara bersamasama.

Kegiatan pelaksanaan penelitian ini sudah diupayakan secara maksimal. Hasil yang diperoleh dari kegiatan penelitian ini menemukan beberapa hal penting yang berkaitan dengan masalah peningkatan prestasi belajar siswa di SD Negeri 4 Sidan dengan menerapkan metode learning starts with a question. Dari hasil analisis yang telah dilakukan, diperoleh kemajuankemajuan yang sesuai harapan yaitu:

- Kemampuan Metode learning starts with a question mampu meningkatkan prestasi belajar siswa sehingga hasil awal yang baru mencapai 69,75 pada siklus I dapat ditingkatkan menjadi 74,75 dan pada siklus II dapat ditingkatkan menjadi 81,5.

- Metode learning starts with a question mampu membantu siswa bekerja lebih giat dan lebih aktif serta bentuk objektif, jujur dan terbuka.

- Metode learning starts with a question mampu membantu siswa menggunakan ingatannya serta transfer ilmu yang lebih sesuai harapan.

Kekurangan-kekurangan yang ada adalah :

- mampu menemukan sendiri tidak terlaksana sesuai harapan. Motivasi belajar siswa yang kurang maksimal menjadi kendala bagi peneliti mengingat banyak peserta didik yang lebih sering melakukan kegiatan dan tidak mau giat untuk belajar.

- Kebiasaan belajar siswa yang masih tradisional yang lebih banyak menunggu perintah dari guru menyebabkan pembelajaran yang seharusnya mereka.

Selanjutnya Metode learning starts with a question telah pula diupayakan dengan bimbingan yang maksimal dalam rangka mengembangkan kemampuan siswa untuk mampu memahami materi dan dalam konsep belajar yang lebih baik. Metode learning starts with a question mampu memberi petunjuk bagi siswa baik pada permulaan belajar, pada kegiatan inti, maupun pada kegiatan akhir. Pembelajaran telah diupayakan dengan memberi pertanyaan-pertanyaan yang menuntun mereka lebih giat dalam menemukan dan membuat mereka berpikir lebih aktif dalam penemuan konsep-konsep yang tepat.

Hasil penelitian ini sejalan dengan hasil penelitian yang dilakukan oleh Haryadi dan Sri (2016) dengan judul Penerapan Model Learning Start With A Question Berpendekatan Icare Pada Hasil Belajar. Hasil penelitian menyimpulkan bahwa model learning start with a question berpendekatan ICARE berpengaruh positif pada hasil belajar dan besarnya kontribusi pengaruh $19,42 \%$.

Selanjutnya penelitian yang dilakukan oleh Purnamasari (2016) dengan judul Penerapan Strategi Learning Start With A Question (LSQ) untuk Meningkatkan Aktivitas dan Hasil Belajar Siswa Pada Mata Pelajaran Ekonomi di Kelas X-7 SMA Laboratorium Undiksha Singaraja Tahun Ajaran 2015/2016. Hasil penelitian menunjukkan bahwa (1) penerapan strategi Learning Start with a Question (LSQ) dapat meningkatkan aktivitas belajar siswa yang ditunjukkan dengan rata-rata skor aktivitas belajar siklus I dengan kategori cukup aktif selanjutnya meningkat dengan kategori aktif pada siklus II. (2) penerapan strategi Learning Start with a Question (LSQ) dapat meningkatkan hasil belajar siswa yang ditunjukkan dengan rata-rata skor hasil belajar siklus I sebesar 79,84 dengan kategori baik selanjutnya meningkat menjadi 87,75 dengan kategori amat baik pada siklus II.

\section{Simpulan}

Pembelajaran dengan penerapan Metode learning starts with a question memiliki dampak positif dalam meningkatkan prestasi belajar siswa di SD Negeri 4 Sidan khususnya mata pelajaran PKn yang ditandai dengan peningkatan ketuntasan belajar siswa dalam setiap siklus, yaitu siklus awal 69,75, siklus I 74,75, dan siklus II 81,5. Selain hal tersebut penerapan Metode learning starts with a question berpengaruh pula meningkatkan kembali materi ajar yang telah diterima siswa selama ini, sehingga mereka merasa siap untuk menghadapi pelajaran berikutnya. 


\section{Daftar Pustaka}

Arikunto, Suharsimi; Suhardjono; Supardi. 2006. Penelitian Tindakan Kelas. Jakarta: PT Bumi Aksara.

Dahar, Ratna Wilis. 1989. Teori-Teori Belajar. Jakarta: Penerbit Erlangga.

Departemen Pendidikan Nasional. 2003. Kurikulum 2004. Jakarta: Depdiknas.

Depdiknas. 2002. Contextual Teaching And Learning. Jakarta: Dirjen Pendidikan Dasar dan Menengah.

Depdiknas. 2011. Membimbing Guru dalam Penelitian Tindakan Kelas. Jakarta: Pusat Pengembangan Tenaga Kependidikan Badan Pengembangan Sumber Daya Manusia Pendidikan Penjaminan Mutu Pendidik.

Dimyati dan Mudjiono. 2001. Belajar dan Pembelajaran. Jakarta: Dirjen Dikti.

Direktorat Tenaga Kependidikan, Direktorat Jendral Peningkatan Mutu Pendidik dan Tenaga Kependidikan. 2008. Metode dan Teknik Supervisi. Jakarta: Depdiknas.

Djamarah, Syaful Bahri. 2002. Prestasi Belajar dan Kompetensi Guru. Surabaya: Usaha Nasional.

Haryadi, Dheni Nur dan Sri Nurhayati. 2016. Penerapan Model Learning Start With A Question Berpendekatan Icare Pada Hasil Belajar. Jurnal Inovasi Pendidikan Kimia, Vol 9, No. 2, 2015, hlm 1528 - 1537.

Purnamasari, Komang Nia. 2016. Penerapan Strategi Learning Start With A Question (LSQ) untuk Meningkatkan Aktivitas dan Hasil Belajar Siswa Pada Mata Pelajaran Ekonomi di Kelas X-7 SMA Laboratorium Undiksha Singaraja Tahun Ajaran 2015/2016. Jurnal Program Studi Pendidikan Ekonomi (JPPE) Volume: 7 Nomor: 2. 